\title{
Ataluren-time for a 'no-nonsense' approach to haematological malignancies
}

\author{
John A. Loudon \\ Correspondence: jon.uk1515@gmail.com \\ Wetherill Park Medical Centre, Sydney, Australia.
}

\begin{abstract}
This article outlines the novel application of Ataluren - a readthrough agent - for the management of a number of haematological malignancies. A broad spectrum of cancers may be managed by this approach from solid-based to blood-borne. The focus here is on representing the spectrum of leukaemias that may be targeted by this novel therapy - as assessed via genetic screening for nonsense mutations in tumour suppressor genes. Reversion of such mutations can be hypothesized to be of significant value in the treatment of adult and childhood nonsense mediated-leukaemias. These are relatively prevalent and suited to the readthrough therapy approach.

Keywords: Acute lymphoid leukaemia, acute myeloid leukaemia, ataluren, chemotherapy, chronic lymphoid leukaemia, chronic myeloid leukaemia, haematologic malignancies, lymphoma, myeloma, myelodysplastic syndrome, nonsense mutation, readthrough, tumour suppressor
\end{abstract}

\section{Correspondence}

Haematological malignancy covers a group of cancers that affect blood, bone marrow and lymph nodes. Oftentimes all locations are affected simultaneously via their immune system interconnection. The cell of origin is both myeloid and lymphoid. Lymphomas, myeloma as well as lymphocytic leukaemias derive from lymphoid cells whereas myelogenous leukaemia, myelodysplastic and myeloproliferative conditions derive from the myeloid lineage.

Means of management of haematological malignancies include chemotherapy, radiotherapy, immunotherapy and, in selected cases, a bone marrow transplant. Treatment with Glivec targeting tyrosine kinase resulting from a specific genetic lesion in CML is proving to be a powerful therapy [1]. Another small molecular therapy is with Ataluren which specifically targets and reverts nonsense mutations - Premature Termination Codons - PTCs, by readthrough [2-4]. This low toxicity agent is being trialed for PTC-mediated cystic fibrosis and muscular dystrophy and can be also considered for use in PTC-mediated cancer and heart diseases [2-4]. Nonsense mutation reversion enables full length, potentially functional proteins, to be produced. The concept for cancer therapy is based on the observation that tumour suppressor genes exhibit a disproportionate number of nonsense mutational changes over oncogenes [4]. PTC mutations present in a whole variety of cancers from solidbased to haematological as can be gleaned from even a brief examination of COSMIC (Catalogue Of Somatic Mutations In Cancer, [4]).

Readthrough therapy of tumour suppressor PTCs in cancer has demonstrated 'proof of concept' for its benefits in cancer therapy in laboratory-based studies [2-4].
In terms of haematological malignancies the following highlight examples of tumour suppressors that may well be potentially excellent substrates for PTC-reversion and therefore could well prove highly efficacious in terms of a novel therapeutic approach. In AML a significant number of PTC-somatic mutations in the transcriptional corepressor gene BCORL 1 from various cell lines have been found [5]. In another instance in regards AML, the tumour suppressor, PHF6, is found to be mutated [6]. Genetic lesions in PHF6 found in AML are both frameshift and nonsense mutations distributed through the gene. Another study [7] unveiled candidate tumour suppressor genes FOXO3 and PRDM1 in Natural Killer (NK)-cell neoplasms that were down-regulated in neoplastic samples. Nonsense mutations of PRDM1 that led to functional inactivation in one cell line and one clinical sample were determined.

The classical tumor suppressor, Tp53 has been examined in leukaemias and in CLL a significant number of PTCs in Tp53 are found [8]. In ALL cell line HPB a novel PTC at codon 124 of Tp53 has been disclosed adding weight to the direct involvement of PTC inactivation of this tumour suppressor in leukaemias [9]. In another study, the majority of Tp53 mutations in myeloma patients were found to be PTCs [10]. Presence of Tp53 mutations was associated with poor survival. Reversion of such Tp53 PTCs in myeloma could therefore prove to be of considerable therapeutic value.

Mutation of cell cycle regulator p16 (CDKN2A) by PTC has been implicated in the genesis of paediatric T-cell acute lymphoblastic leukaemia [11]. Another cell cycle regulator, CDKN1B, has a tumor suppressor role and a PTC mutation found with tumour-tissue only in a case of acute lymphomatous adult T-cell leukaemia suggests a causative role [12]. A nonsense mutation in one 


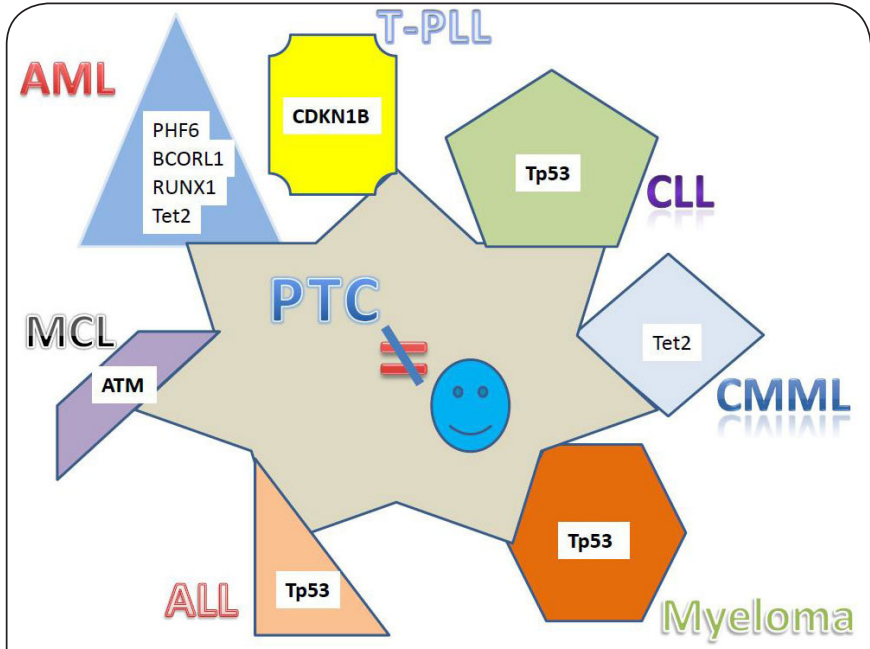

Figure 1. Haematological malignancies related to PTCs: ALL - Tp53 [9]; AML - BCORL1 [5], PHF6 [6], Tet2 [17,18], Runx1 [19]; CLL - Tp53 [8]; Chronic myelomonocytic leukemia(CMML) - Tet2 [18]; Mantle cell lymphoma (MCL) - ATM [14]; Myeloma - Tp53 [10]; T-cell prolymphocytic leukemia (T-PLL) - CDKN1B [13].

Table 1. Frequencies of somatic PTCs in selected key tumour suppressor genes as annotated on COSMIC for Haematopoietic and Lymphoid malignancies.

\begin{tabular}{lc}
\hline Gene & Number of unique PTCs \\
\hline ATM & 16 \\
CDKN2A & 4 \\
MLH1 & 1 \\
MSH2 & 1 \\
PHF6 & 14 \\
PRDM1 & 4 \\
PTEN & 14 \\
Rb & 2 \\
RUNX1 & 14 \\
Tet2 & 1902 \\
Tp53 & 25 \\
\hline
\end{tabular}

allele of CDKN1B in a case of T-cell prolymphocytic leukaemia implicates CDKN1B haploinsufficiency as a mechanism in the pathogenesis of this leukaemia [13]. PTC reversion of this allele can be predicted to be of therapeutic value in this case.

PTC mutation of ATM tumour suppressor has been linked to cancer formation [4]. Various somatic as well as germline ATM nonsense mutations have been implicated as causally related to mantle cell lymphoma - a non-Hodgkin's lymphoma [14]. Clearly, PTC reversion therapy could have a novel key role to play here.

A significant number of PTC mutations are potentially causatively related to PTEN tumour suppressor inactivation in radiation-induced thymic lymphomas in mice [15]. Again, this suggests investigating a place for reversion therapy targeting this suppressor gene in various human lymphoid neoplasms.

Tet2 is a tumor suppressor frequently mutated in haem- atological malignancies [16]. Tet methylcytosine dioxygenase 2 , whose function is not entirely understood, may have a significant role in epigenetic regulation. A study has shown that a majority of tet 2 mutations were of the nonsense type in patients with primary cytogenetically normal AML [17]. These patients had shorter event-free survival and therefore these mutations not only serve as useful prognostication markers but also as targets for PTC-based readthrough. Tet2 nonsense mutations have been observed in chronic myelomonocytic leukemia, AML and myeloproliferative neoplasms and relate to poorer prognosis in AML [18]. Doubtlessly, any means to revert tet2 PTCs would be highly valuable therapeutically in these instances.

Finally, a PTC in the RUNX1/AML1 tumour suppressor gene, a known mutational target in $\mathrm{AML}$, has been detected by whole transcriptome sequencing [19]. Again, this forms a useful target for Ataluren-based PTC-directed reversion therapeutics.

One caveat ought to be mentioned and that concerns drug resistance. As in most cancer therapies, resistance to chemotherapeutic agents occurs and Ataluren readthrough therapy may not be immune to that feature [2]. Time will tell to what degree this is of significance though in regards haematological malignancies yet clinicians should be aware of the potential for such an event.

Figure 1 summarizes a number of the above studies relating PTC and tumour suppressor genes in haematologic malignancies. Frequencies of somatic PTCs in selected key tumour suppressor genes in haematologic malignancies as annotated on COSMIC are listed in Table 1.

To conclude, PTCs are ubiquitous in leukaemias and inactivate a number of important malignancy-related tumour suppressor genes thereby decreasing vital intracellular levels of the protein product. In such a fashion, PTCs have a potentially causative role in haematologic malignancies. Reversion of these by low-toxicity small molecular agents such as Ataluren could be predicted to be of considerable value and a most useful addition to the therapeutic armamentarium of haemato- oncologists around the World. Thus the time is now right to commence clinical trials of Ataluren-based PTC readthrough therapy for haematological malignancies. Our future patients may well thank us for that!

\section{Competing interests}

The author declares no competing interests.

Publication history

Received: 21-Feb-2013 Accepted: 2-Mar-2013

Published: 06-Mar-2013

\section{References}

1. Loudon JA, Coleman HG, Allen CM, Schifter M, Ng T, Al-Horani G: Rare oral manifestation of chronic myelogenous leukemia and its targeted therapy: A case report and literature review. Univ J Med Dent 2012, 1: 79-85. I Pdf

2. Loudon JA: Ataluren: A 'no-nonsense' approach for pulmonary diseases. Pulm Pharmacol Ther 2013. | Article I PubMed 
John A. Loudon Hematology and Leukemia 2013,

3. Loudon JA: Ataluren: Time for a 'No-Nonsense' Approach to Heart Diseases. Cardiovasc Drugs Ther 2013. | Article | PubMed

4. Loudon JA: Cancer: a novel "no-nonsense" approach to treatment. Oncol Res 2010, 19:55-66. | Article | PubMed

5. Li M, Collins R, Jiao Y, Ouillette P, Bixby D, Erba H, Vogelstein B, Kinzler KW, Papadopoulos N and Malek SN: Somatic mutations in the transcriptional corepressor gene BCORL1 in adult acute myelogenous leukemia. Blood 2011, 118:5914-7. | Article | PubMed Abstract | PubMed Full Text

6. Van Vlierberghe P, Patel J, Abdel-Wahab O, Lobry C, Hedvat CV, Balbin M, Nicolas C, Payer AR, Fernandez HF, Tallman MS, Paietta E, Melnick A, Vandenberghe P, Speleman F, Aifantis I, Cools J, Levine R and Ferrando A: PHF6 mutations in adult acute myeloid leukemia. Leukemia 2011, 25:130-4. | Article | PubMed

7. Karube K, Nakagawa M, Tsuzuki S, Takeuchi I, Honma K, Nakashima Y, Shimizu N, Ko YH, Morishima Y, Ohshima K, Nakamura S and Seto M: Identification of FOXO3 and PRDM1 as tumor-suppressor gene candidates in NK-cell neoplasms by genomic and functional analyses. Blood 2011, 118:3195-204. | Article | PubMed

8. Zenz T, Vollmer D, Trbusek M, Smardova J, Benner A, Soussi T, Helfrich $H$, Heuberger M, Hoth P, Fuge M, Denzel T, Habe S, Malcikova J, Kuglik P, Truong S, Patten N, Wu L, Oscier D, Ibbotson R, Gardiner A, Tracy I, Lin K, Pettitt A, Pospisilova S, Mayer J, Hallek M, Dohner H and Stilgenbauer S: TP53 mutation profile in chronic lymphocytic leukemia: evidence for a disease specific profile from a comprehensive analysis of 268 mutations. Leukemia 2010, 24:2072-9. | Article | PubMed

9. Smardova J, Pavlova S, Svitakova M, Grochova D and Ravcukova B: Analysis of p53 status in human cell lines using a functional assay in yeast: detection of new non-sense p53 mutation in codon 124. Oncol Rep 2005, 14:901-7. | Article | PubMed

10. Chng WJ, Price-Troska T, Gonzalez-Paz N, Van Wier S, Jacobus S, Blood E, Henderson K, Oken M, Van Ness B, Greipp P, Rajkumar SV and Fonseca R: Clinical significance of TP53 mutation in myeloma. Leukemia 2007, 21:582-4. | Article | PubMed

11. Kawamura M, Ohnishi H, Guo SX, Sheng XM, Minegishi M, Hanada R, Horibe K, Hongo T, Kaneko Y, Bessho F, Yanagisawa M, Sekiya T and Hayashi Y: Alterations of the p53, p21, p16, p15 and RAS genes in childhood T-cell acute lymphoblastic leukemia. Leuk Res 1999, 23:115-26. | Article | PubMed

12. Morosetti R, Kawamata N, Gombart AF, Miller CW, Hatta Y, Hirama T, Said JW, Tomonaga M and Koeffler HP: Alterations of the p27KIP1 gene in non-Hodgkin's lymphomas and adult T-cell leukemia/lymphoma. Blood 1995, 86:1924-30. | Article | PubMed

13. Le Toriellec E, Despouy G, Pierron G, Gaye N, Joiner M, Bellanger D, Vincent-Salomon A and Stern MH: Haploinsufficiency of CDKN1B contributes to leukemogenesis in T-cell prolymphocytic leukemia. Blood 2008, 111:2321-8. | Article | PubMed

14. Camacho E, Hernandez L, Hernandez S, Tort F, Bellosillo B, Bea S, Bosch F, Montserrat $E$, Cardesa $A$, Fernandez PL and Campo E: ATM gene inactivation in mantle cell lymphoma mainly occurs by truncating mutations and missense mutations involving the phosphatidylinositol-3 kinase domain and is associated with increasing numbers of chromosomal imbalances. Blood 2002, 99:238-44. | Article | PubMed

15. Yamaguchi Y, Takabatake T, Kakinuma S, Amasaki Y, Nishimura M, Imaoka T, Yamauchi K, Shang Y, Miyoshi-Imamura T, Nogawa H, Kobayashi Y and Shimada Y: Complicated biallelic inactivation of Pten in radiationinduced mouse thymic lymphomas. Mutat Res 2010, 686:30-8. | Article I PubMed

16. Mercher T, Quivoron C, Couronne L, Bastard C, Vainchenker W and Bernard OA: TET2, a tumor suppressor in hematological disorders. Biochim Biophys Acta 2012, 1825:173-7. I Article I PubMed

17. Metzeler KH, Maharry K, Radmacher MD, Mrozek K, Margeson D, Becker H, Curfman J, Holland KB, Schwind S, Whitman SP, Wu YZ, Blum W, Powell BL, Carter TH, Wetzler M, Moore JO, Kolitz JE, Baer MR, Carroll AJ, Larson RA, Caligiuri MA, Marcucci G and Bloomfield CD: TET2 mutations improve the new European LeukemiaNet risk classification of acute myeloid leukemia: a Cancer and Leukemia Group B study. J Clin Oncol 2011, 29:1373-81. | Article | PubMed Abstract | PubMed Full Text

18. Abdel-Wahab O, Mullally A, Hedvat C, Garcia-Manero G, Patel J, Wadle- igh M, Malinge S, Yao J, Kilpivaara O, Bhat R, Huberman $\mathrm{K}$, Thomas $\mathrm{S}$, Dolgalev I, Heguy A, Paietta E, Le Beau MM, Beran M, Tallman MS, Ebert BL, Kantarjian HM, Stone RM, Gilliland DG, Crispino JD and Levine RL: Genetic characterization of TET1, TET2, and TET3 alterations in myeloid malignancies. Blood 2009, 114:144-7. | Article | PubMed Abstract | PubMed Full Text

19. Greif PA, Eck SH, Konstandin NP, Benet-Pages A, Ksienzyk B, Dufour A, Vetter AT, Popp HD, Lorenz-Depiereux B, Meitinger T, Bohlander SK and Strom TM: Identification of recurring tumor-specific somatic mutations in acute myeloid leukemia by transcriptome sequencing. Leukemia 2011, 25:821-7. | Article | PubMed

Citation:
Loudon J A: Ataluren-time for a 'no-nonsense'
approach to haematological malignancies.
Hematology and Leukemia 2013, 1:2.
http://dx.doi.org/10.7243/2052-434X-1-2

